\title{
Oxygen Consumption in the Bottom Water Related with the Production of Sulfides in the Bottom Sediments
}

\author{
Akira KAWAI ${ }^{* 1}$ and Hiroto MAEDA ${ }^{* 2}$ \\ (Accepted April 28, 1983)
}

\begin{abstract}
The dissolved oxygen consumption of the overlying water was studied in the north and south basins of Lake Biwa. DO consumption due to the bottom sediment was estimated from the dissolved oxygen uptake in the core tube. Chemical oxygen uptake in the bottom sediment core were measured separately from total uptake by supplimentation of formalin or mercury chloride. Total DO consumption rates in the north and south basins averaged $0.4 \mathrm{~g} \mathrm{O}_{2} / \mathrm{m}^{2} /$ day and $0.02 \mathrm{~g} \mathrm{O}_{2} / \mathrm{m}^{2} /$ day, respectively. Chemical oxygen uptake accounted for about $80 \%$ and $17 \%$ of the total oxygen uptake in the north and south basins. The sulfides accumulation was found to be much higher in the north basin than in the south basin.

In both the basins, the concentration of sulfides in the bottom sediment was correlated with chemical DO consumption in the overlying water. Regression analysis suggests that sulfide formation in the bottom sediment is the dominant factor controlling chemical DO consumption in each basin.
\end{abstract}

One of the most undesirable environmental conditions in water regions might be "deficiency of dissolved oxygen" in the water, or the formation of anoxic layer in the bottom water. Mainely, dissolved oxygen in sufficient level is essential not only for the growth of fish and shellfish, but also for keeping appropriate quality of water. The concentration of dissolved oxygen in the water is governed by the difference in the rates of the diffusion from atmosphere and consumption in the water body.

Although a certain amount of oxygen is used in the process of oxidative decomposition of organic materials in eutrophicated water, the consumption of dissolved oxygen seems largely to be responsible for the oxidation of sulfides which are produced microbiologically in bottom sediments followed by liberation into the overlying water.

The major process of producing sulfides is thought to be dissimilatory sulfate reduction by microorganismus, ${ }^{13}$ whereas they are partly produced microbial decomposition of sulfur-containing organic compounds. The former process is performed by sulfate reducing bacteria, which reduce sulfate to sulfide in coupling with the hydrogen donation from some organic compounds. In addition to the physiology and biochemistry of each species of the bacterial group, thier sulfide formation in the bottom sediments of various water regions has been studied in details. ${ }^{2,3)}$ The organic compounds which can be utilized directly and served as hydrogen donors in the bacterial sulfate reduction are reported to be acetic, formic, pyruvic and lactic acids, etc. ${ }^{2,4}$

Despite these findings, actual circumstances as to in situ contribution of organic acids to the sulfide production in bottom sediment are still obscure. From the viewpoint, the authors have intended to reveal the mechanism of the formation of oxygen deficient layers in coastal and inland water, focusing the studies on the in situ productions of sulfides and organic acids in connection with decomposition of organic matter, and further on the consumption of dissolved oxygen in the water-sediment interface.

This paper deals with the actual distribution and seasonal variation of dissolved oxygen in the water as well as the sulfide concentration in the bottom sediment, in the north and south basins of Lake Biwa. Further, in situ rate of oxygen consumption in the bottom water has been estimated by the use of a newly deviced technique.

*1 Depertment of Fisheries, Faculty of Agriculture, Kinki University, Kowakae, Higashi-Osaka 577, Japan (河合 章: 近畿大学震学部).

*2 Laboratory of Microbiology, Depertment of Fisheries, Faculty of Agriculture, Kyoto University, Kyoto 606, Japan（前田広人：京都大学露学部). 


\section{Materials and Methods}

\section{Outline of the Water Regions Studied}

Lake Biwa is the largest lake in Japan, whose area is approximately $690 \mathrm{~km}^{2}$ and maximum depth is $104 \mathrm{~m}$. The lake is divided limnologically into two basins, i.e. the large, deep, oligotrophic north basin and the small, shallow eutrophic south basin. The lake has numerous inlet streams and an outlet, the Seta River, at the southwestern end of the south basin. In this experiment, two sampling stations, Station A (depth, ca. $80 \mathrm{~m}$ ) and Station B (depth, ca. $3 \mathrm{~m}$ ), were set up in each basin as shown in Fig. 1.

\section{Collection of Samples}

The bottom sediment samples were collected by

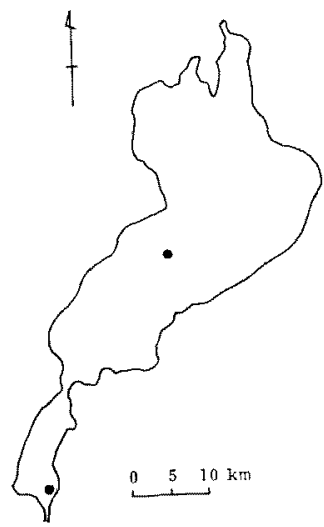

Fig. 1. Stations set up at the north and south_basins of Lake Biwa.

a
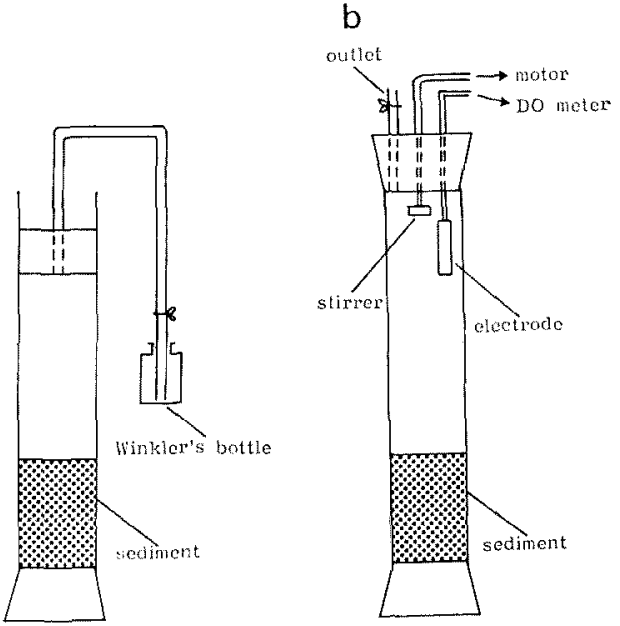

Fig. 2. Experimental apparatus for measuring dissolved oxygen consumption by Winkler's method (a) and DO meter (b). the use of a KK core sampler (the original design was reported Kimata ${ }^{\text {() }}$ ) equipped with a plastic tube of a $5 \mathrm{~cm}$ inside diameter. For the chemical analysis, the sediment column was sliced into each $0.5 \mathrm{~cm}$ or $1.0 \mathrm{~cm}$ thickness on board, and put into a plastic bottle, sealed tightly, then brought into the labratory keeping at $0^{\circ} \mathrm{C}$ in the ice box.

\section{Measurement of DO Consumption}

Following two methods were employed in the measurement of in situ rate of oxygen consumption in the overlying water of the tubes.

(1) Measurement of oxygen consumption by the Winkler's method

Just after collecting a core sample on board, the upper end of a core tube was sealed with a rubber stopper connected with a rubber tube (Fig. 2a), to intersept the bottom water from atmosphere. The core tubes were kept at the definite temperatures throughout the experiment. At a definite interval bottom water was collected into Winkler's oxygen bottoles, then determined the decrease of dissolved oxygen in the overlying water.

(2) Measurement of oxygen consumption by DO meter

The core tube collected were sealed with a rubber stopper at each end on board. At the measurement of dissolved oxygen, the rubber stopper at the upper end was replaced with the stopper equiped with a DO senser and a stirrer (Fig. 2b). Time course of DO concentration in the overlying water was traced using DO meter (Toshiba Beckman Fieldlab Oxygen Analyzer) at verious temperature.

\section{Physical and Chemical Analyses}

The in situ temperature and dissolved oxygen of the water were measured by Portable Water Pollution Monitor WP-2 (Kyoto Denshi Kogyo). Total Sulfides in the bottom sediment was trapped into $\mathrm{Zn}$ acetate solution by the steam distilation under acidic condition. ${ }^{6)}$ The trapped sulfide was determined colorimetrically by the method of Shinra. ${ }^{\tau}$ Free sulfide in the bottom sediment was released by steam distillation without acid supplementation.

\section{Results}

Seasonal Changes in Water Temperature and DO Concentration

The seasonal and vertical distributions of temperature and dissolved oxygen in the water of north 

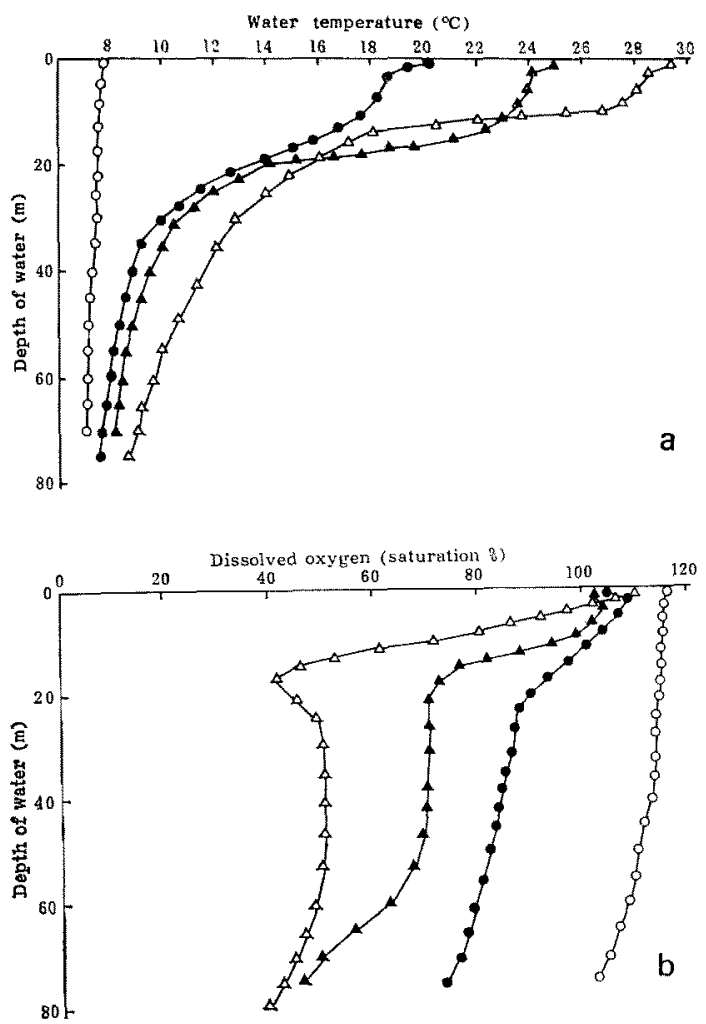

Fig. 3. Seasonal and vertical distributions of temperature (a) and dissolved oxygen (b) in the water of north basin in 1981.

O: March, $\bullet:$ July, $\triangle$ : August, $\Delta$ : September.

basin were shown in Fig. 3a and Fig. 3b. In the summer, the stratification due to temperature was recognized clearly in the water colum of the north basin, whereas the water temperature was almost constant all the year round in the hypolimnion (Fig. 3a). On the other hand, DO in the hypolimnion fluctuated seasonally, and DO in the bottom water fell down as low as 38 saturation \% in the summer season, which may be ascribed to that the DO consumption in the bottom water exceeds the diffusion of atmospheric oxygen into the bottom water across the thermocline.

Seasonal changes in water temperature and DO in the water of south basin were shown in Table 1. The temperature of bottom water fluctuated seasonally, maximum temperature of $26^{\circ} \mathrm{C}$ was observed in August and decreased to below $8^{\circ} \mathrm{C}$ in December. Despite a marked seasonal change in the bottom temperature, DO value was almost constant in the bottom water. This may be due to the diffusion of atmospheric oxygen into such shallow bottom water in the south basin.

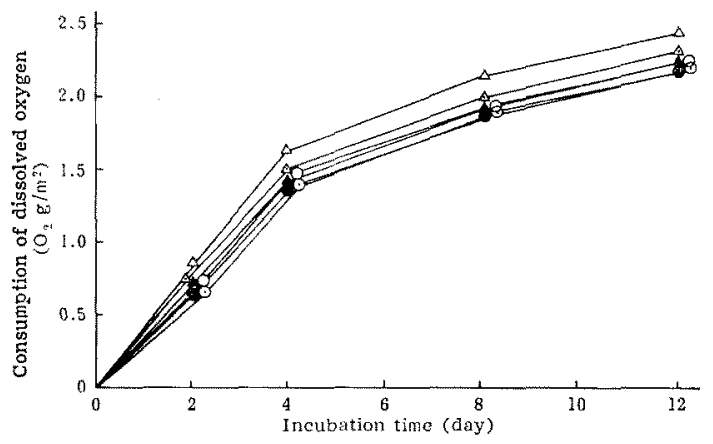

Fig. 4. Dissolved oxygen consumption by the bottom sediment in the overlying water of the north basin.

$O$ : incubated at $0^{\circ} \mathrm{C}, \odot$ : incubated at $0^{\circ} \mathrm{C}$ in the presence of formaldehyde, 0 : incubated at $0^{\circ} \mathrm{C}$ in the presence of mercury chloride, $\Delta$ : incubated at $8^{\circ} \mathrm{C}, \Delta$ : incubated at $8^{\circ} \mathrm{C}$ in the presence of formaldehyde, $\Delta$ : incubated at $8^{\circ} \mathrm{C}$ in the presence of mercury chloride.

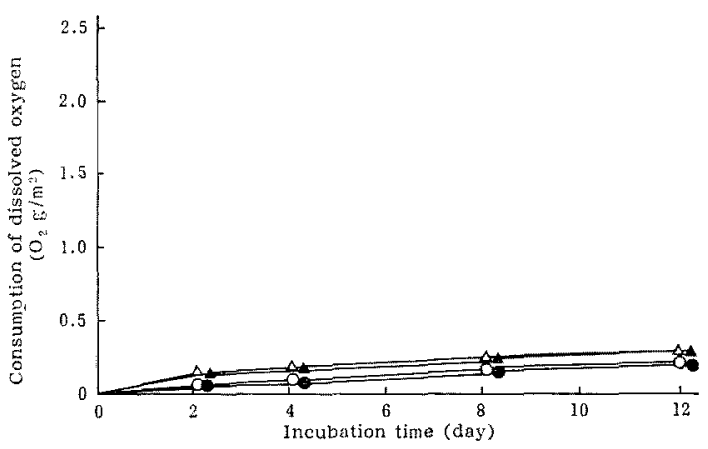

Fig. 5. Dissolved oxygen consumption by the bottom sediment in the overlying water of the south basin.

$O$ : incubated at $0^{\circ} \mathrm{C}$, incubated at $0^{\circ} \mathrm{C}$ in the presence of mercury chloride, $\Delta$ incubated at $25^{\circ} \mathrm{C}, \triangle$ : incubated at $25^{\circ} \mathrm{C}$ in the presence of mercury chloride.

Table 1. Dissolved oxygen in the south basin of Lake Biwa in 1981

\begin{tabular}{crrrrr}
\hline \multirow{2}{*}{ Month } & \multicolumn{5}{c}{ Dissolved oxygen (saturation \%) } \\
\cline { 2 - 6 } & April & June & August & October & December \\
\hline Surface water & 105 & 106 & 100 & 110 & 113 \\
Overlying water & 95 & 97 & 97 & 102 & 104 \\
\hline
\end{tabular}



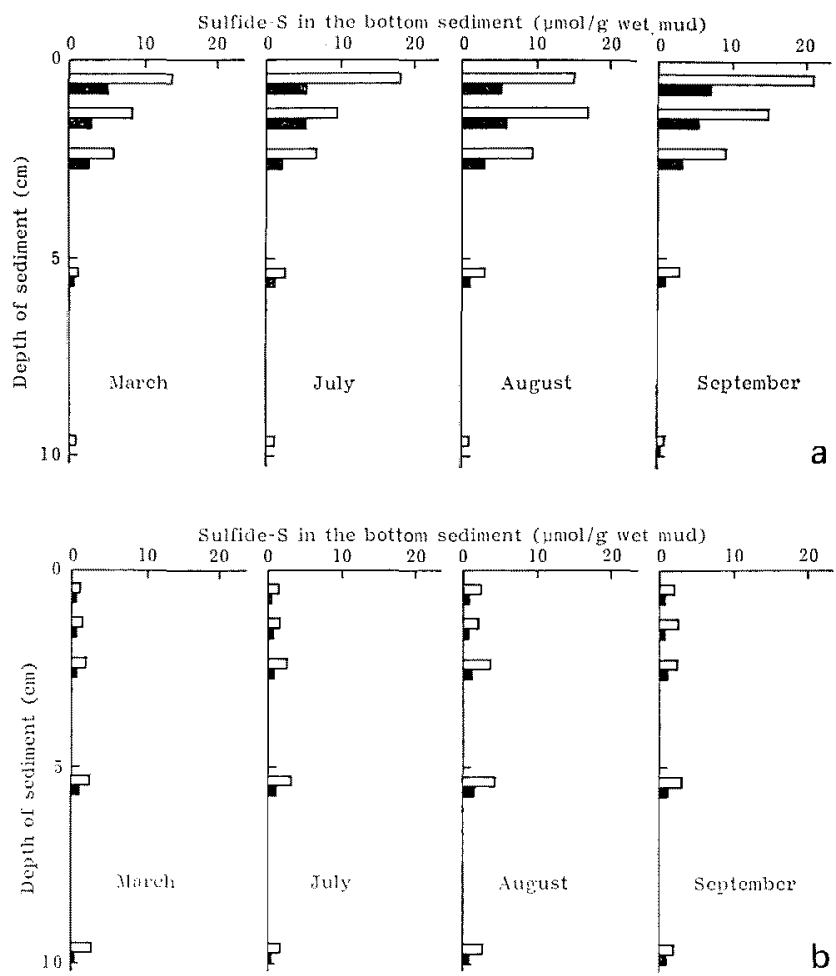

Fig. 6. Seasonal and vertical distribution of total and free sulfides in the north (a) and south (b) basins.

$\square$ total sulfides, free sulfide.

Table 2. The rate of biological and chemical Do consumption in the north and south basins of Lake Biwa in 1981

\begin{tabular}{|c|c|c|c|c|c|c|c|c|}
\hline \multirow{2}{*}{$\begin{array}{l}\text { Station } \\
\text { Month }\end{array}$} & \multicolumn{4}{|c|}{ North basin } & \multicolumn{4}{|c|}{ South basin } \\
\hline & Mar. & Jul. & Aug. & Sep. & Mar. & Jul. & Aug. & Sep. \\
\hline $\begin{array}{l}\text { Biological DO consumption } \\
\quad\left(\mathrm{g} \mathrm{O}_{2} / \mathrm{m}^{2} / \text { day }\right)\end{array}$ & 0.08 & 0.09 & 0.11 & 0.12 & 0.02 & 0.05 & 0.16 & 0.17 \\
\hline $\begin{array}{l}\text { Chemical DO consumption } \\
\qquad\left(\mathrm{g} \mathrm{O}_{2} / \mathrm{m}^{2} / \text { day }\right)\end{array}$ & 0.28 & 0.29 & 0.31 & 0.32 & 0.01 & 0.02 & 0.03 & 0.01 \\
\hline
\end{tabular}

Consumption of Dissolved Oxygen in the Overlying Water

The DO consumption by the bottom sediment in the overlying water of the north basin was shown in Fig. 4. To measure the oxygen consumption based on chemical processes separately from total oxygen uptake in the overlying water, sufficient amount of formaldehyde $(5 \%$ in final concentration) or mercury chloride ( $2 \mathrm{ppm}$ in final concentration) was added to the core tubes, then incubated at $0^{\circ} \mathrm{C}$. Under this condition, the lowest oxygen consumption was observed. The DO consumption incubated at $0^{\circ} \mathrm{C}$ without the inhibitor was slightly higher than that with the inhibitor. This shows that the biological oxygen uptake was al- most inhibited and that oxygen uptake under such condition may be due to chemical oxidation. The DO consumption at in situ temperature $\left(8^{\circ} \mathrm{C}\right)$ was a little higher than that in the presence of the inhibitor at $0^{\circ} \mathrm{C}$. The difference may be attributed to biological process. From these results, it is evident that the DO consumption in the overlying water in the north basin is performed mainly by the chemical oxidation rather than biological oxygen uptake.

The DO consumption in the overlying water in the south basin was shown in Fig. 5. The result shows that the biological respiration occupied the most part of in situ DO consumption.

In comparison with south basin, the total DO 
consumption was higher in the north basin, but biological oxygen uptake was almost at the same level in both basin. From this finding, it is clear that the difference between north basin and south basin in the DO consumption in the overlying water was ascribable to the difference of chemical oxidation based on the bottom sediment.

\section{Distribution of Sulfides in the Bottom Sediment}

Seasonal and vertical distribution of total and free sulfides in both basins were shown in Fig. $6 \mathrm{a}$ and Fig. 6b. In the north basin, the concentration of total and free sulfides did not change vertically all the year round. The ratio of free sulfide to total sulfide was almost constant, i.e. about $30 \%$ in the bottom sediment from near surface until ca. $10 \mathrm{~cm}$ depth. In the south basin, total and free sulfides were found to increase in summer at the surface layer of bottom sediment and decrease in winter at near surface of bottom sediment. With regard to the ratio of free sulfide to total sulfides, the bottom sediment of south basin had a similar tedency as that of north basin.

The Rate of DO Consumption in Overlying Water

Table 2 shows the rate of biological and chemi- cal DO consumption in the north and south basins in different seasons. The rate of DO consumption calculated using equation of Michealis-Menten. As a result, the values of north basin hardly change all the year round. The chemical oxygen uptake was approximately three times higher than the biological oxygen uptake in the north basin. In south basin, the DO consumption was found to increase in summer and decrease in winter. Thus, in contrast with north basin, the DO consumption in south basin was largely reasponsible for the biological respiration.

\section{Discussion}

Average anual oxygen uptake of bottom sediment in Lake Biwa (south basin $0.12 \mathrm{~g} \mathrm{O}_{2} / \mathrm{m}^{2} /$ day and north basin $0.4 \mathrm{~g} \mathrm{O}_{2} / \mathrm{m}^{2} /$ day) seems to be as the similar level as the already reported values (0.02-3.9 $\mathrm{g} \mathrm{O}_{2} / \mathrm{m}^{2} /$ day) (Table 3).

In the south basin, average biological oxygen uptake could acount for about $80 \%$ of total oxygen uptake. Since the epiphytic algae and benthic animals were scarcely found in the core tube, bacterial oxygen uptake would be most part of the

Table 3. Respiration of various sediment systems

\begin{tabular}{|c|c|c|}
\hline Community & $\begin{array}{c}\text { Average Respiration } \\
\mathrm{g} \mathrm{O}_{2} / \mathrm{m}^{2} / \text { day }\end{array}$ & Reference \\
\hline River mud & 2.4 & Edwards and Rolley ${ }^{14)}$ \\
\hline Freshwater lake & 0.35 & Hargrave $^{15 ?}$ \\
\hline Georgia sublittoral & $\begin{array}{ll}2.6 & \text { biological } \\
2.8 & \text { total }\end{array}$ & Smith $^{18)}$ \\
\hline Atlantic slope & 0.017 & Smith and Teal ${ }^{17 i}$ \\
\hline San Diego trough & $\begin{array}{l}0.04 \text { biological } \\
0.08 \text { total }\end{array}$ & Smith $^{19)}$ \\
\hline Intertidal salt marsh, $\mathrm{Ga}$. & 3.9 & Teal and Kanwisher ${ }^{10)}$ \\
\hline Salt marsh mud, La & $\begin{array}{ll}0.45 \text { biological } \\
0.8 \text { total }\end{array}$ & Hopkinson et al..$^{9}$ \\
\hline Danish fjord & 1.2 & Jørgensen ${ }^{1)}$ \\
\hline South basin of Lake Biwa & $\begin{array}{l}0.10 \text { biological } \\
0.12 \text { total }\end{array}$ & This study \\
\hline North basin of Lake Biwa & $\begin{array}{l}0.10 \text { biological } \\
0.40 \text { total }\end{array}$ & This study \\
\hline
\end{tabular}

Table 4. The diffusion coefficient calculated from the rate of DO consumption and the concentration of free sulfide

\begin{tabular}{cccc}
\hline Station & $\begin{array}{c}\text { Rate of DO } \\
\text { consumption } \\
\left(\mu \mathrm{mol} / \mathrm{cm}^{2} / \mathrm{sec}\right)\end{array}$ & $\begin{array}{c}\text { Concentration of } \\
\text { free sulfide* } \\
(\mu \mathrm{mol} / \mathrm{g} \text { wet mud })\end{array}$ & $\begin{array}{c}\text { Diffusion } \\
\text { coefficient } \\
\left(\mathrm{cm}^{2} / \mathrm{sec}\right)\end{array}$ \\
\hline North basin & $1.4 \times 10^{-8}$ & 3.1 & $6.0 \times 10^{-6}$ \\
South basin & $0.4 \times 10^{-8}$ & 0.8 & $6.3 \times 10^{-6}$
\end{tabular}

\footnotetext{
* concentration of free sulfide in the sediment of $0 \sim 0.5 \mathrm{~cm}$ depth.
} 
biological oxygen uptake. Hargrave ${ }^{\text {s) }}$ reported that bacterial respiration was directly related to temperature in Marion Lake. Further, Hopkinson $^{\text {B) }}$ suggested that the magnitude and temporal patterns of benthic respiration are a function of rate to supply of organic material in Lousiana saltmarsh. In agreement with their finding, seasonal change in DO consumption rate in the south basin, as shown in Table 2, may support a correlation between oxygen uptake and water temperatures which increase in summer and decrease in winter.

In the north basin, the chemical process occupied most part of DO consumption. The rate of DO consumption in the north basin scarcely changed all the year round. The rate of chemical oxygen uptake to whole DO consumption was nearly constant (Table 2). Gardner and Lee ${ }^{10)}$ have reported that the rate of chemical DO consumption was found to be dependent on temperature and ferrous iron content of sediment in Lake Mendota. On the other hand, Nikaido ${ }^{11)}$ demonstrated that the oxygen consumption by reduced sulfur compound in the lake sediment depends on the amounts of sulfide-S and humic substances. In this study, the concentrations of total and free sulfides as well as temperature in the sediment of north basin were found to be scarcely changed as shown in Fig. 6a. From these findings, the chemical DO consumption in the overlying water in the north basin might be mainly responsible for reduced sulfur compounds liberated from the sediment. In the chemical process of sulfide oxidation, there forms stable elemental sulfur. ${ }^{12}$ If the reduction $2 \mathrm{H}_{2} \mathrm{~S}+\mathrm{O}_{2} \rightarrow 2 \mathrm{~S}+\mathrm{H}_{2} \mathrm{O}$ proceeds in the sediment-water interface, 1 mole of oxygen should be consumed by 2 moles of hydrogen sulfide. Then, DO consumption rate in the overlying water by hydrogen sulfide may be a function of its liberation rate, $\mathrm{L}=\Phi \mathrm{D}(\mathrm{Ca}-\mathrm{Cb} / \mathrm{dZ})$ where $\mathrm{L}$ : rate of sulfide liberation; $\Phi$ : porosity; $\mathrm{D}$ : diffusion coefficient; $\mathrm{Ca}$ : concentration of free sulfide in the bottom sediment of depth $\mathrm{dZ} ; \mathrm{Cb}$ : concentration of free sulfide in the overlying water (assumed as 0 in the bottom water of the south and north basin). Table 4 shows the diffusion coefficient calculated from the equation, in which the $1 / 2$ rate of DO consumption was given as $\mathrm{L}$. The obtained values were
$6.0 \times 10^{-6}$ in the north basin and $6.4 \times 10^{-6}$ in the south basin, respctively. Kamiyama et $a l^{18}$ have already found the diffusion coefficient of ammonium nitrogen in the bottom sediment in Lake Biwa to be $4 \sim 2 \times 10^{-8}$. This value coincides with the diffusion coefficient calculated from the DO consumption in this study, which suggests that the rate of chemical DO consumption in the overlying water in the both basins depends mainly on the amount of sulfides in the bottom sediment.

\section{References}

1) B. B. JøRGENSEN: Limnol. Oceanogr., 22814 834 (1977).

2) J. R. Postgate: The Sulfate Reducing Bacteria, Cambridge University press, London, 1979, pp. 46-96.

3) B. B. JøRGENSEN: Mar. Biol., 41, 7-17, (1977).

4) H. Mryoshi: Mem. Fac. Agr. Kochi Univ., 18, 134-183 (1967).

5) M. KimatA, A. KaWAI, and Y. Ishma: Bull. Japan. Soc. Sci. Fish., 26, 1223-1230 (1960).

6) T. Tomyama: Bull. Japan. Soc. Sci. Fish., 17, 115-119 (1959).

7) K. ShInra: Mizu-bunseki, Kyoritsu, Tokyo, 1957, pp. 25.

8) B. T. Hargrave: J. Fish. Res. Bd. Canada, 26, 2003-2026 (1969).

9) C. S. Hopkinson, J, W. DAY, Jr. and B. T. Geal: An. Centro Cienc. del Mar y Limnol. Univ. Nal. Auton. Mexico, 5, 225-238 (1978).

10) W. Gardner and G. F. Lee: Int. J. Air Wat. Poll., 9, 553-564 (1965).

11) M. Nikaido: Mem. Ehime Univ., Sci., Ser. B (Biol.), 5, 21-32 (1971).

12) C. E. Zobell: Organic Geochemistry, Pergamon Press, Oxford, 1963, pp. 543-578.

13) K. Kamyama: Jap. J. Limnol., 37, 59-66 (1976).

14) R. W. Edwards and H. Rolley: J. Ecology, 53. 1-19 (1965).

15) B. T. HaRgrave: Limnol. Oceanogr., 14, 801805 (1969).

16) K. L. SмitH: Ecology, 54, 1065-1075 (1973).

17) K. L. SMIth and J. M. TEAL: Science, 179, 282283 (1973).

18) K. L. SMith: Limnol. Oceanogr., 19, 939-944 (1974).

19) J. M. TEAL and J. KANWISHER: Limnol. Oceanogr., 6, 388-39; (1961). 